\title{
ANFIS Controller Based Speed Control of High-Speed BLDC Motor Drive
}

\author{
TMuthamizhan $^{\mathrm{a}, 1}$, D SilasStephen ${ }^{\mathrm{b}}$ and ASivakumar \\ ${ }^{a}$ Associate Prof, Deptof EEE, Sri Sairam Institute of Technology, Chennai \\ ${ }^{b}$ Professor, PanimalarEngineering College, Chennai, India \\ ${ }^{c}$ Associate Professor, Panimalar Engineering College, Chennai, India
}

\begin{abstract}
The paper aims to define the speed control of Brushless DC Motor (BLDC) drive using an Adaptive Neuro Fuzzy Interface System (ANFIS) controller. ANFIS controller-based switching scheme reduces the power quality issues present in the system by minimizing the Total Harmonic Distortion (THD). Incremental conductance algorithm-based control technique for the Maximum Power Point Tracking (MPPT) in variable solar irradiation conditions for photovoltaic (PV) system is proposed. INC algorithm are used to operate the photovoltaic panels at maximum power, by generating PWM pulse to control the flyback converters in differential power processing mode. BLDC motor drive is electronically commutated by means of switching logical pulses from the rotor position sensor using PI controllers. The simulation shows the significance and robustness of BLDC drive and the results offered illustrates the intended control is effective, with fast responseandminimum settling times.
\end{abstract}

Keywords. Photovoltaic, Incremental Conductance, flyback converter, adaptive neurofuzzy control, BLDC.

\section{Introduction}

The power density and higher efficiency of Permanent magnet (PM) motors finds applications in industrial automation and consumer electric appliances. ThePMmotor drives are classified into PMACmotorswith sinusoidal back EMF and brushless dc (BLDC) motors with trapezoidal back EMF. The PMAC motor are excited by 3- $\phi$ sinusoidal current, whereas thePMBLDC motor are driven by currents oftrapezoidal waveform. BLDC motor are sparkless with fewer loss, more efficiency, noise free, faster response and sparkless due to the absence of brushes. The BLDC control is intended to get faster response for the speed variations imposed on the motor, makes the system dynamically stable with less steady state error.

The controllers of Artificial Intelligence techniques like Fuzzy controller, ANFIS and few expert systems are being widely used inthe various application. ANFIS based controller is proposed in the research work for the speed control of BLDC motor. ANFIS is a rule-based system, highly stable, acts faster with less steady state error and improves the system response superior to that of fuzzy logic controller.

\footnotetext{
${ }^{1}$ T Muthamizhan, Associate prof,Dept of EEE, Sri Sairam Institute of Technology, Chennai; Email : muthamizhan@gmail.com
} 
Mathematical model of BLDC model design controlled by ANFIS controller is compared with the performance with fuzzy controller in [1], torque ripple is minimized using the torque controller for BLDC motor using unideal back emf [2], torque ripple minimization using dq reference frame and indirect stator flux control using d-axis [4] and speed control using hall effect sensor fixed in stator of BLDC [3]. PFC correction using Cuk converter fed BLDC drive using current/voltage follower approach for [5], using Bridgeless-Luo Converter Fed BLDC Drive[11], PFC and speed control using BL-CSC Converter Fed BLDC Motor Drive[10], Performance of BLDC motor fed by solar energy and control by electronic commutation [6], solar PV with grid interactive BLDC drive for water pumping system with bidirectional power transfer and without current sensor is studied [7]. Solar PV with differential power processing converters techniques using least power point tracking algorithms [8] and the DPP converter with current Sensorless topology for PV panels under partial shading condition in [12]. Sensorless control of high-speed BLDC drive with speed control system with the commutation errors compensation [9] is studied. From the above studies it is suggested that an DPP converter with PV Source for speed control of high-speed BLDC motor.

\section{Photovoltaic System}

From the global mix of energy sources, the renewables include, geothermal, hydrothermal, biomass, wind and photovoltaics. Of the available sources, Clean Source for the energy generation is photovoltaic energy and the deployment costs not competent with the initial installed costs of fossil fuels for electrical energy generation. The parameters of Trina Solar TSM-220PA05.30 module is tabulated in Table 1. The PV characteristics of one solar panel, for different solar irradiance level ranging from $0.1 \mathrm{KW} / \mathrm{sq} . \mathrm{m}$ to $1 \mathrm{~kW} / \mathrm{Sq} . \mathrm{M}$ is shown in figure 1 . The IV and $\mathrm{PV}$ characteristics of a solar array with 14 series module, one parallel string is shown in figure 2. The net current through the PV cell is given by the difference of the photovoltaic current ILand the normal diode current Ioand it is given by

$$
I=I_{L}-I_{o}\left[e^{\frac{q(V+1 R S)}{n K T}}-1\right]
$$

The RS represents the resistance present in each PV cell given by the relation (2).

$$
R_{S}=-\frac{d V}{d I_{V_{O C}}}-\frac{1}{x_{V}}
$$

The open circuit voltage of the PV module is given by the equation (3).

$$
V_{O C}=\frac{n K T}{q} \ln \frac{l_{L}+l_{0}}{l_{0}}
$$

The Fill Factor of the solar cell may be greater than or equal to 0.7 , derived by the equation (4)

$$
F F=\frac{P_{\max }}{V_{O C} I_{S C}}=\frac{V_{\max } I_{\max }}{V_{O C} I_{S C}}
$$




\section{Control Approach}

The proposed control system has four significant parts; solar PV control through MPPT strategy, Differential processing of power of each PV panel, control of permanent magnet BLDC motor through electronic commutationand the speed control of BLDC motor by ANFIS Controller.

\subsection{Maximum Power Point Tracking (Incremental Conductance Algorithm)}

The maximum power point variation on the solar panel depends on the angle with the sunlight impinges over the solar panel (angle of incidence), irradiation and the cell temperature. This work aims to explore and extract the maximum power from the solar PV modules by means of maximum power point tracking system using Incremental Conductance (INC) algorithm. The duty cycle of flyback converter on differential power processing mode is controlled by INC algorithm to ensure maximum power point at its maximum efficiency. INC algorithm was proposed to get control of the downside of $\mathrm{P} \& \mathrm{O}$ algorithmandto progress the energy extract from the solar panel by reducing the tracking time for a wide range of irradiation change. INC calculation is recognized in the way that slope of characteristic is zero at the MPP. If $\mathrm{dPpv} / \mathrm{dVpv}$ is negative then MPPT is lies on the right side of recent position and if the $\mathrm{dPpv} / \mathrm{dVpv}$ is positive the MPPT is on left side. In INC algorithm, the duty cycle control (D) is implemented to realize the maximum power point, the control variable perturbs with constant pulse width and rate bestowing to the power slope until the operating point reaches MPP.

\subsection{Differential Power Processing (DPP) on Flyback Converter}

In the differential power processing (DPP) strategy, the converters are classified into four categories, of the available converters, substring-to-bus equalization architecture are used here. Bidirectional fly back converter-based DPP converters, transfer power between the bus and each substring, and the architectures require multiple DPP converters in proportion to the number of substrings, likely increasing the system complexity and cost. Here 2 DPP converters is used in this research work, Module integrated converters (MIC) with a centralized inverter, keeps track of high MPPT efficiency even in partial shading conditions.

In this architecture, individual converter achieves maximum power point (MPP)separatelybased on the distributed maximum power point tracking (DMPPT) control concept. In distributed power sourceswhich experience frequent partial shading, DMPPT transfer more efficiency, where each solar panel is controlled by a separate controller. 


\subsection{ANFIS Controller and commutation of BLDC motor.}

Adaptive network based fuzzy inference system (ANFIS) is a neuro-fuzzy technique, in which the combination is made between the neural network and the fuzzy inference system, has been used as the primary tool in this research work. In this ANFIS controller take in sense the adaptability of the neural network and the uncertainty and imprecision of the fuzzy logic. This hybrid model will initially use the fuzzy model with its variables and the rules forms the input and models the output data. The neural network then fine tunes the fuzzy rules to produce the ANFIS Model. Fuzzy inference is to model the structure of the system, virtually designed by the user's discernment of a variable in the inference system. The change in variable parameter are augmented with a gradient vector, are used as reference to FIS with the pre-determined parameters to measure the input/output data. BLDC motor is an PMAC motor, whose mechanical characteristics impersonates the dc motor characteristics. Instead of commutating using commutator/ brushes as in de motor, electronic commutation is used here in PMBLDC motors, the stator windings are turned ON and OFF with the help of power semiconductor switches from the symmetrical dc current drawn from Voltage Source Inverter for $120^{\circ}$ and positioned at the centre of back-EMF. In the stator, Hall sensors positioned at 180 o produce Hall signals $(\mathrm{H} 1, \mathrm{H} 2, \mathrm{H} 3)$ at an interval of $60^{\circ}$ in congruence with the rotor position and the switching states of VSI as shown in table I.

Table 1. Switching States for electronic commutation of BLDC motor

\begin{tabular}{|c|c|c|c|c|c|c|c|c|c|}
\hline \multirow[t]{2}{*}{$\mathbf{e}^{0}$} & \multicolumn{3}{|c|}{ Hall signals } & \multicolumn{6}{|c|}{ Switching States } \\
\hline & H1 & H2 & H3 & S1 & S2 & $\mathbf{S 3}$ & S4 & S5 & S6 \\
\hline NA & 0 & 0 & 0 & 0 & 0 & 0 & 0 & 0 & 0 \\
\hline $0-60$ & 0 & 0 & 1 & 1 & 0 & 0 & 0 & 0 & 1 \\
\hline $\begin{array}{c}60- \\
120\end{array}$ & 0 & 1 & 0 & 0 & 1 & 1 & 0 & 0 & 0 \\
\hline $\begin{array}{l}120- \\
180\end{array}$ & 0 & 1 & 1 & 0 & 0 & 1 & 0 & 0 & 1 \\
\hline $\begin{array}{l}180- \\
240\end{array}$ & 1 & 0 & 0 & 0 & 0 & 0 & 1 & 1 & 0 \\
\hline $\begin{array}{l}240- \\
300\end{array}$ & 1 & 0 & 1 & 1 & 0 & 0 & 1 & 0 & 0 \\
\hline $\begin{array}{l}300- \\
360\end{array}$ & 1 & 1 & 0 & 0 & 1 & 0 & 0 & 1 & 0 \\
\hline NA & 1 & 1 & 1 & 0 & 0 & 0 & 0 & 0 & 0 \\
\hline
\end{tabular}

\section{Simulated Performance}

Now a days, an alternate for the DC motor is a brushless DC (BLDC) motor and the proposed test system is shown in the figure 1. The electric and magnetic loadings of the motor are made highto gain maximum power density for BLDC motor, where high electric loading requires a high coercivity and imposes a long magnet length in the direction of magnetization and limited by demagnetizing effect and thermal factors.Highmagnetic loading/airgap flux density requires the largest possible magnet volume, proportional to remanent flux densityandproportionate to its pole face area. 
Due to the small phase number (typically three) in thebldc motor, the electronic commutation is very stiff related to that of a mechanical commutator, which has at least 12 segments and sometimes a few hundred.

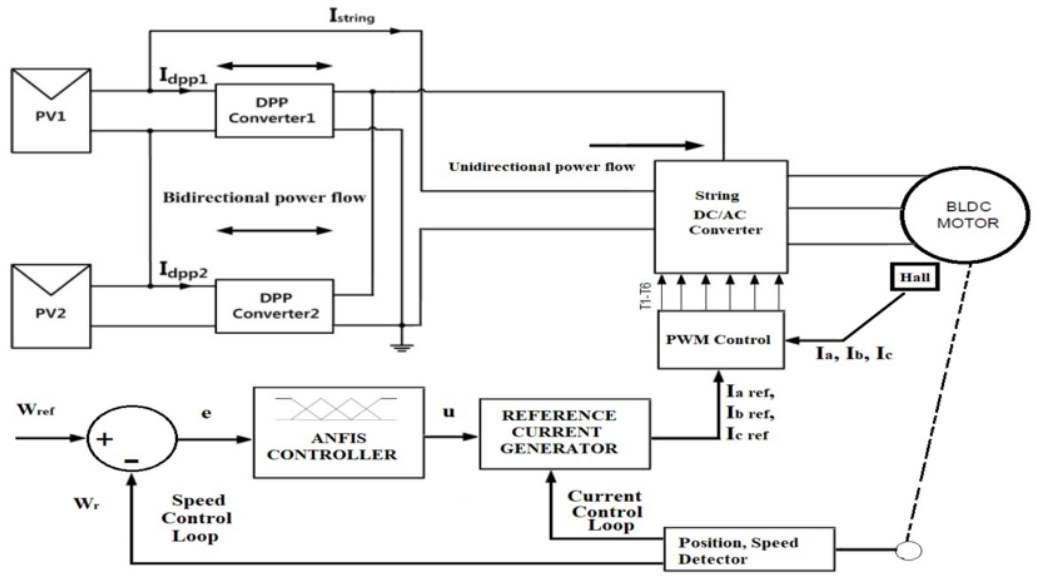

Figure 1. Block Diagram of ANFIS controlled BLDC drive.

The measured speed is compared with reference speed and the error speed is reduced by ANFIS controller closer to reference, by current control using rotor position sensing. The power from the PV panels using differential power processing technique is controlled by electronic commutation and ANFIS controller, and the torque ripple is minimized. The parameters of a 3 phase, star connected BLDC motor is given in table II and the MATLAB/ SIMULINK diagram of the closed loop controlled flyback converter in differential power processing mode fed from string dc/ac converter to a PMBLDC drive System fed from PV Source is presented in figure 2.Three phase voltage and current wave form of BLDC motor is shown in the figure 3 and the back emf waveform for the three phases are presented.

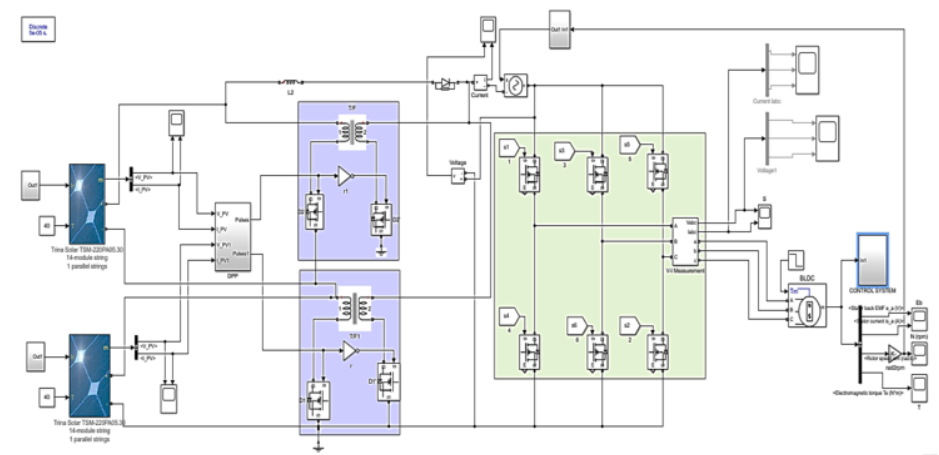

Figure 2. Simulink Diagram of the Closed Loop Controlled Flyback Converter fed PMBLDC drive System fed from PV Source. 
Table 2. Parameters of BLDC motor

\begin{tabular}{cc}
\hline \multicolumn{1}{c}{ Parameter } & Value \\
\hline Motor type & Ametek 119003-01 \\
Rated current & $6.8 \mathrm{~A}$ \\
Rated Speed & $4228 \mathrm{rpm}$ \\
Number of Phase(connection) & $3(\mathrm{star})$ \\
Stator resistance (R) & $0.348 \Omega$ \\
Stator inductance $(\mathrm{L})$ & $0.314 \mathrm{mH}$ \\
Voltage constant $(\mathrm{Ke})$ & $0.0419 \mathrm{~V} / \mathrm{rad} / \mathrm{s}$ \\
Torque constant $(\mathrm{Kt})$ & $4.19 \mathrm{Ncm} / \mathrm{A}$ \\
Number of Pole $(\mathrm{P})$ & 8 \\
\hline
\end{tabular}
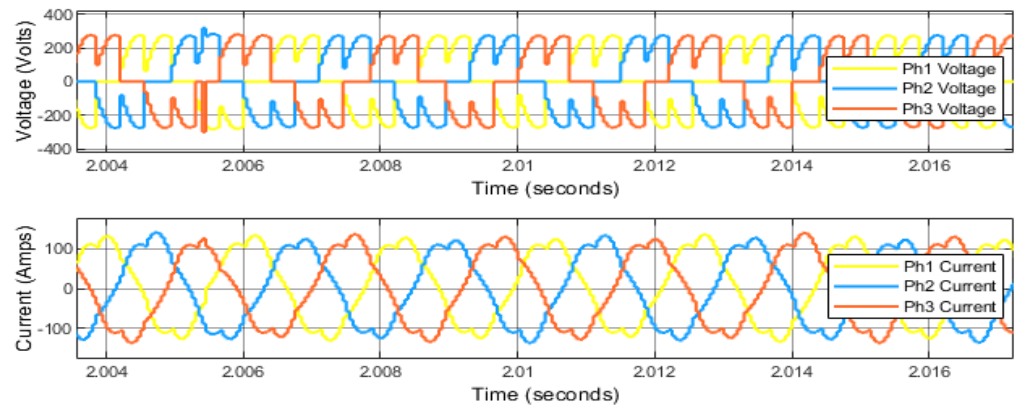

Figure 3. Phase Voltage and current of PMBLDC drive System fed from PV Source.
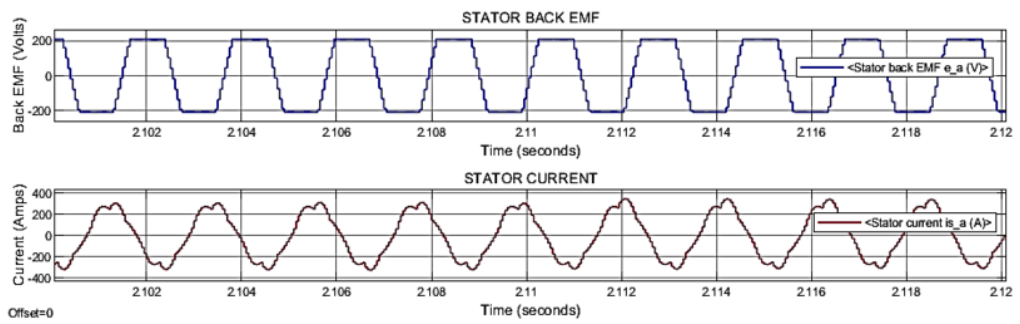

Figure 4. Stator voltage and current of PMBLDC motor.

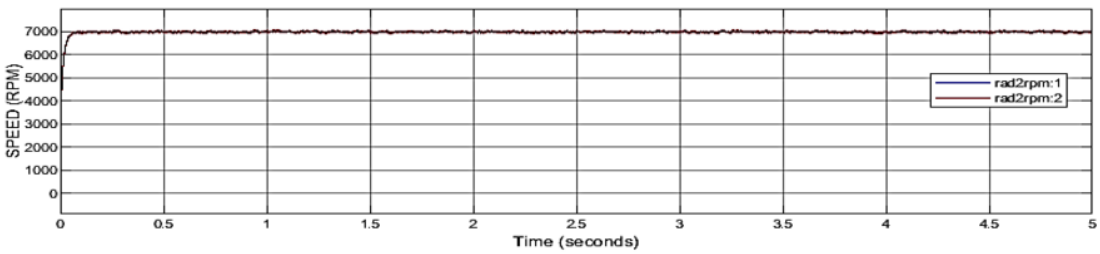

Figure 5. Speed of the PMBLDC motor. 

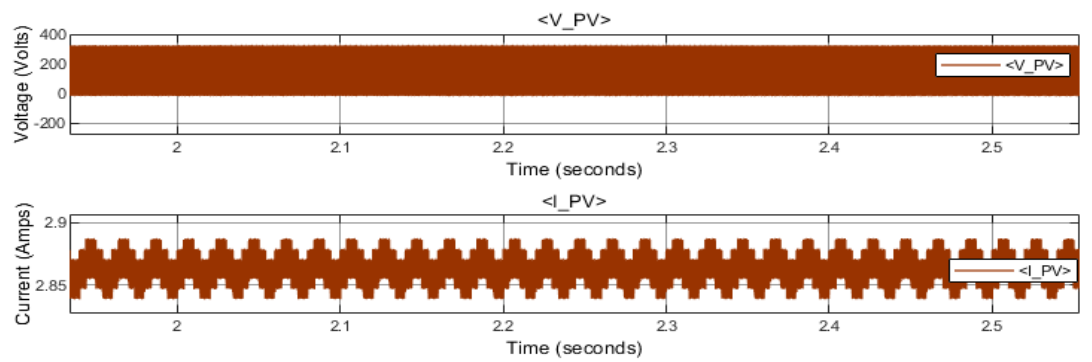

Figure 6. Voltage and current waveform of the PV Source.
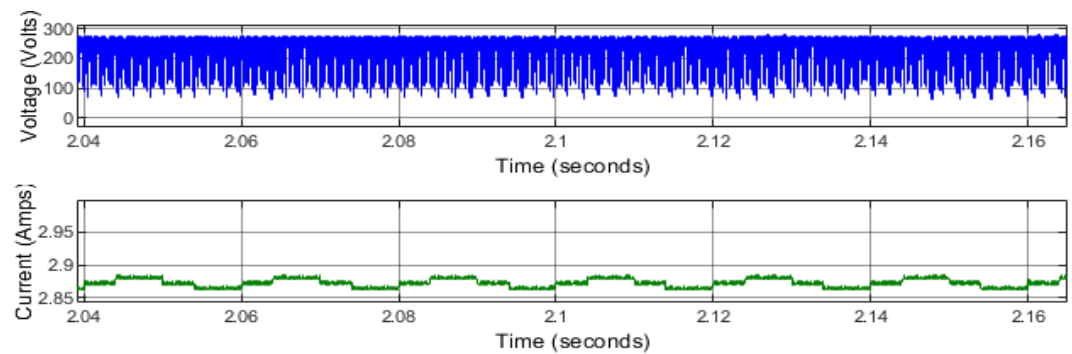

Figure 7. Voltage and current waveform of the PV Source.

Stator voltage and current waveform for one phase(phase-A) of BLDC motor is presented in the figure 4 and the speed waveform for the same is presented in figure 5.

The motor reaches the steady state at 0.05 seconds. The voltage $\left(\mathrm{V}_{\mathrm{PV}}\right)$ and current (I $\mathrm{PV}$ ) waveform of the PV module 1 is shown in figure 6 . The voltage and current waveform of the differential power processing of flyback converters is shown in figure 7. The frequency spectrum of a PMBLDC motor fed from PV source in DPP mode is shown in Figure 8 . With constant load, the THD is $20.28 \%$ when the motor is operated at $50 \mathrm{~Hz}$ frequency.

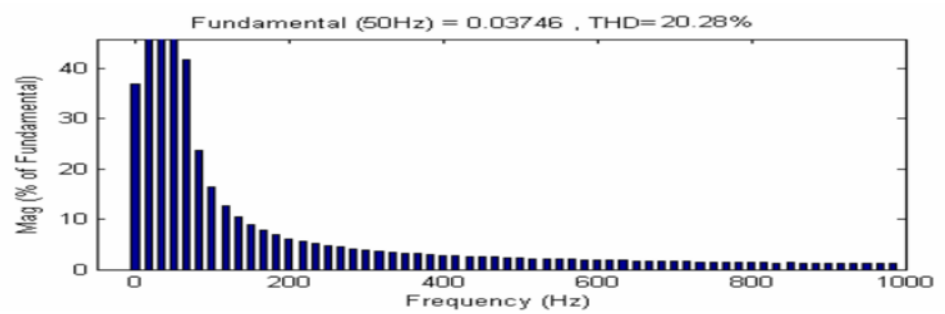

Figure 8. THD of fed PMBLDC drive System fed from PV Source/DPP flyback converter.

\section{Conclusion}

The paper outlines the speed control of BLDC motor drive using ANFIS controller, with improved power quality and the THD of the system is found as $20.28 \%$. INC algorithm was used to track the MPPin variable solar irradiation circumstances. DC voltage to the inverters are generated using DPP from the flyback converters. The results reveal that the speed control of BLDC motor is through with ANFIS controller has robustness for high performance applications. From simulation results, it is proved 
that the controller gives a more operative, shows fast response for a given input. These analyses are useful in the design of control strategies to improve the motor performance.

\section{References}

[1] M. Yashoda and O. Chandra Sekhar, Design and Analysis of ANFIS based BLDC Motor.Indian Journal of Science and Technology, 9(35), (2016)

[2] H. Lu, L. Zhang, and W. Qu, A New Torque Control Method for Torque Ripple Minimization of BLDC Motors With Un-Ideal Back EMF.IEEE Transactions on Power Electronics, 23(2),(2008).

[3] H. Wu, M. Wen, and C. Wong, Speed Control of BLDC Motors Using Hall Effect Sensors Based on DSP.(2016) International Conference on System Science and Engineering (ICSSE), National Chi Nan University, Taiwan, July 7-9, 2016

[4] S. B. Ozturk and H. A. Toliyat, Direct Torque and Indirect Flux Control of Brushless DC Motor.IEEE/ASME Transactions on Mechatronics, 16(2), (2011), pp.351-360.

[5] V. Bist, and B. Singh, PFC CukConverter Fed BLDC Motor Drive.IEEE Transactions on Power Electronics,

[6] R. Kumar and B. Singh.Single Stage Solar PV Fed Brushless DC Motor Driven Water Pump.IEEE Journal of Emerging and Selected Topics in Power Electronics

[7] R. Kumarand B. Singh.Grid Interactive Solar PV Based Water Pumping Using BLDC Motor Drive.IEEE Transactions on Industry Applications

[8] Y. Jeon, H. Lee, K.A. Kim, and J. Park, Least Power Point Tracking Method for Photovoltaic Differential Power Processing Systems.IEEE Transactions on Power Electronics, DOI 10.1109/TPEL.2016.2556746

[9] G. Liu, C. Cui, K. Wang, B. Han and S. Zheng.Sensorless Control for High-speed Brushless DC Motor Based on the Line-to-line Back-EMF.IEEE Transactions on Power Electronics

[10]B. Singh and V. Bist, A BL-CSC Converter Fed BLDC Motor Drive with Power Factor Correction.IEEE Transactions on Industrial Electronics

[11]B. Singh, V. Bist, A. Chandra and K. Al-Haddad, Power Factor Correction in Bridgeless-LuoConverter Fed BLDC Motor Drive.IEEE Transactions on Industry Applications 